\title{
The green synthesis, characterization, and evaluation of the biological activities of silver nanoparticles synthesized from Leptadenia reticulata leaf extract
}

\author{
M. Kumara Swamy • K. M. Sudipta • \\ K. Jayanta $\cdot$ S. Balasubramanya
}

Received: 12 December 2013/ Accepted: 16 January 2014/Published online: 5 February 2014

(C) The Author(s) 2014. This article is published with open access at Springerlink.com

\begin{abstract}
Biosynthesis of silver nanoparticles (Ag Nps) was carried out using methanol leaves extract of $L$. reticulata. Ag Nps were characterized based on the observations of UV-visible spectroscopy, transmission electron microscopy, and X-ray diffraction (XRD) analysis. These Ag Nps were tested for antimicrobial activity by agar well diffusion method against different pathogenic microorganisms and antioxidant activity was performed using DPPH assay. Further, the in vitro cytotoxic effects of $\mathrm{Ag}$ Nps were screened against HCT15 cancer cell line and viability of tumor cells was confirmed using MTT ((3-(4,5-dimethylthiazol-2-yl)-2,5-diphenyltetrazolium bromide, a yellow tetrazole)) assay. The nuclear condensation was studied using the propidium iodide-staining method. The color change from green to dark brown and the absorbance peak at about $420 \mathrm{~nm}$ indicated the formation of nanoparticles. XRD pattern showed characteristic peaks indexed to the crystalline planes (111), (200) and (220) of face-centered cubic silver. The nanoparticles were of spherical shape with varying sizes ranging from 50 to $70 \mathrm{~nm}$. Biosynthesized $\mathrm{Ag}$ Nps showed potent antibacterial activity and effective radical scavenging activity. MTT assay revealed a dosedependent decrease in cell viability. Microscopic observations showed distinct cellular morphological changes indicating unhealthy cells, whereas the control appeared normal. Increase in the number of propidium iodide positive cells were observed in maximum concentration. Methanolic
\end{abstract}

M. Kumara Swamy $(\bowtie) \cdot$ S. Balasubramanya

Rishi Foundation, 2365, 19th Cross, Banashankari 2nd Stage,

Bangalore 560070, India

e-mail: swamy.bio@gmail.com

K. M. Sudipta $\cdot$ K. Jayanta

Padmashree Institute of Management and Sciences,

Kommagatta, Bangalore 560060, India leaf extract of $L$. reticulata acts as an excellent capping agent for the formation of silver nanoparticles and demonstrates immense biological activities. Hence, these Ag NPs can be used as antibacterial, antioxidant as well as cytotoxic agent in treating many medical complications.

Keywords Leptadenia reticulata $\cdot$ Nanoparticles · Green synthesis $\cdot$ TEM $\cdot$ XRD $\cdot$ Biological activities

\section{Introduction}

In this era, nanotechnology is one of the most interesting areas which are used to describe the creation and utilization of materials with structural features between those of atoms and bulk materials with at least one dimension in the nano range. Nanoparticles are atomic or molecular aggregates with at least one dimension between 1 and $100 \mathrm{~nm}$ that can drastically modify their physico-chemical properties compared to the bulk material. It is worth noting that nanoparticles can be made from a full variety of bulk materials and that they can explicate their actions depending on both the chemical composition and on the size and/or shape of the particles (Brunner et al. 2006). Nanoparticles have been known to be used for numerous physical, biological, and pharmaceutical applications (Rai et al. 2009). Processes used for nanoparticles synthesis are chemical, physical, and a recently developed biological method. Chemical methods have various drawbacks including the use of toxic solvents, generation of hazardous by-products, and high energy consumption, which pose potential risks to human health and to the environment. Therefore, the biological method has an advantage over chemical and physical methods of nanoparticle synthesis, as it is cost-effective and environmentally friendly (Nabhikha et al. 2009). However, these methods 
also have the drawback of being rather slow (Balaji et al. 2009). The major biological systems involved in this are bacteria, fungi, and plant extracts (Prabhu and Poulose 2012). In recent years, the biosynthesis of nanoparticles using plant extracts has gained more importance. The synthesis and applications of silver nanoparticles from several plants have been studied by many researchers (Ankamwar et al. 2005; Kumar et al. 2010; Saxena et al. 2010; Ahmad et al. 2010). In most of the therapeutic applications, it is the antimicrobial property that is being majorly explored, though anti-inflammatory property, cytotoxicity and antioxidants have their fair share of applications.

Leptadenia reticulata (Retz) Wight \& Arn. belonging to family Asclepiadaceae is an important endangered medicinal plant. In India it is found in Gujarat, Punjab, Himalayan ranges, Konkon, Nilgiris, and Southern part of India (Sudipta et al. 2011). The various reports on its multiple uses in curing several diseases such as hematopoiesis, emaciation, cough, dyspnoea, fever, burning sensation, and night blindness draw the attention for utilization of this plant as drugs. It is regarded as good cure for tuberculosis and effectively used for several ear and nose problems. $50 \%$ methanolic extract of this plant is having antibacterial activity and is used for the treatment of skin infection and wounds (Sivarajan and Balachandran 1994). Anjaria in 1967 tried Leptaden tablets (a formulation from Leptadenia reticulata) on some clinical cases and reported its beneficial use as galactogogue for increasing milk (Anjaria and Gupta 1967). Hence in this study, for the first time we evaluated the synthesis and biological activities of Ag NPs using leaf extract of $L$. reticulata.

\section{Materials and methods}

\section{Chemicals}

The chemical silver nitrate $\left(\mathrm{AgNO}_{3}\right)$, Mueller-Hinton agar (MHA), and Sabouraud dextrose agar (SDA) were purchased from Hi Media Laboratories Mumbai, India. Tissue culture plastic wares were obtained from Tarsons Products Pvt. Ltd., India. All organic solvents used were of HPLC grade. RPMI 1640, fetal bovine serum (FBS), and MTT (3(4, 5-dimethyl-thiazol-2-yl)-2, 5-diphenyltetrazolium bromide) were purchased from Sigma Aldrich, India.

\section{Collection of plant material}

Healthy, disease-free leaves of Leptadenia reticulata were collected during the month of April in 2013 from in and around the Padmahree Campus, Kommagatta, Sulikeri post of Bangalore, India. The collected leaves were washed thoroughly in tap water and then in detergent water and were finally rinsed with distilled water until no foreign material remained. The freshly cleaned leaves were left to dry in sun light for approximately 10 days.

Preparation of the plant extract

The leaves $(20 \mathrm{~g})$ were washed twice in tap water and rinsed thrice in distilled water. Then they were surface sterilized by $\mathrm{HgCl}_{2}(0.1 \%)$ for $1 \mathrm{~min}$, cut into small pieces, dried in the micro-oven, and ground into powder using an electronic blender. About $100 \mathrm{~g}$ of leaf powder material was uniformly packed into a thimble and run in soxhlet extractor. It was extracted with methanol for the period of about 5-6 cycles. After that extracts were filtered with the help of Whatman No. 1 filter paper. The filtrates were then evaporated under reduced pressure and dried using a rotary evaporator at $55^{\circ} \mathrm{C}$. Then the extract was kept in refrigerator at $4{ }^{\circ} \mathrm{C}$ for future experiments.

Synthesis of silver nanoparticles (Ag NPs)

For reduction of silver ions, $10 \mathrm{ml}$ of collected filtrate was treated with $90 \mathrm{ml}$ of silver nitrate aqueous solution $(21.2 \mathrm{~g}$ of $\mathrm{AgNO}_{3}$ powder in $125 \mathrm{ml}$ of Milli Q water) and incubated at room temperature for $10 \mathrm{~min}$, resulting in the formation of yellowish to bright yellow and to dark brown color indicating the synthesis of silver nanoparticles (Parashar et al. 2009). After $8 \mathrm{~h}$ of incubation, the solution was centrifuged with $12,000 \mathrm{rpm}$ for $20 \mathrm{~min}$, and their pellets were redispersed in sterile distilled water. The centrifugation and redispersion were repeated three times to ensure the complete separation of nanoparticles. After drying, purified nanoparticles were resuspended in deionized water and stored in a freezer for further study.

Characterization of nanoparticles

UV-Vis spectroscopy

About $1 \mathrm{ml}$ (diluted with 1:20 V/V Milli Q water) of plantpart-synthesised silver nanoparticle solution was monitored in UV-Vis spectrophotometer (Elico, India) (between 300 and $700 \mathrm{~nm}$ ) with different time intervals (15 and $30 \mathrm{~min}$; 4,6 , and $8 \mathrm{~h}$ ).

\section{Transmission electron microscopy (TEM)}

Transmission electron microscope (TEM) analysis was done using JEM-1200EX electron microscope (JEOL, Japan). Thin films of sample were prepared on a carboncoated copper grid by just dropping a very small amount of sample on the grid, extra solution was removed using a blotting paper, and then the film on the TEM grid were 
allowed to dry by putting it under incubator. In this technique, whereby a beam of electronics is transmitted through an ultra-thin specimen, interacting with the specimen as it passes through. An image is formed from the interaction of the electrons transmitted through the specimen. The image is magnified and focused on to an imaging device.

\section{$X$-ray diffraction analysis $(X R D)$}

XRD measurements of the silver nanoparticle solution drop-coated on glass were done on a XRD-6000 X-ray diffractometer model (Shimadzu, Japan) with $40 \mathrm{kV}$, $30 \mathrm{~mA}$ with $\mathrm{Cu} k \alpha$ radiation at $2 \theta$ angle.

Evaluation of antibacterial activity

The silver nanoparticles (Ag NPs) synthesized using $L$. reticulata leaves extract were tested for antimicrobial activity by agar well diffusion method against different pathogenic microorganisms Escherichia coli (E. coli), Klebsiella pneumoniae (K. pneumoniae) (Gram negative), Streptococcus pneumoniae (S. pneumoniae), Micrococcus luteus (M. luteus), and Bacillus subtilis (B. subtilis) (Gram positive). The pure cultures of bacteria were subcultured on MHA. Each strain was swabbed uniformly onto the individual plates using sterile cotton swabs. Wells of $8 \mathrm{~mm}$ diameter were made on nutrient agar plates using gel puncture. Using a micropipette, different concentrations $(25,50,75,100,150 \mu \mathrm{g} / \mathrm{ml})$ of nanoparticle solution was poured onto each well on all plates. After incubation at $37^{\circ} \mathrm{C}$ for $24 \mathrm{~h}$, the diameter of zone inhibition was measured in millimeter, and was recorded as mean $\pm \mathrm{SD}$ of the triplicate experiments.

Studies on antioxidant activity

\section{DPPH free radical scavenging assay}

The DPPH free radical scavenging assay was conducted based on the method of (Chang et al. 2002; Dipankar and Murugan 2012). One milliliter of $0.1 \mathrm{mM}$ DPPH (in ethanol) was added to different concentrations (100, 200, 300, 400 , and $500 \mu \mathrm{g} / \mathrm{ml}$ ) of methanolic leaf extract of $L$. reticulata and its Ag NPs. The reaction mixture was shaken and incubated in the dark for $30 \mathrm{~min}$. The absorbance at $517 \mathrm{~nm}$ was measured against a blank (ethanol). Ascorbic acid was used as the standard and the control was prepared as described above without a sample. The lower absorbance of the reaction mixture indicated a higher percentage of scavenging activity. The percentage of inhibition or scavenging of free radicals was determined by the following formula:
$\%$ Inhibition $=\frac{\text { control OD }- \text { sample OD } \times 100}{\text { control OD }}$

Cytotoxity test of biosynthesized Ag NPs on human colon cancer cell line HTC15

\section{Cell viability assay}

HCT15 cell line was purchased from National Centre for Cell Science (NCCS), Pune, India. The cell line was grown in Dulbecco's modified Eagle's medium (DMEM) supplemented with $2 \mathrm{mM}$ L-glutamine, $100 \mathrm{U} / \mathrm{ml}$ penicillin, $100 \mathrm{~g} / \mathrm{ml}$ streptomycin, and $10 \%$ fetal bovine serum (FBS). Cells were cultured in $75 \mathrm{~cm}^{2}$ cell culture flasks at $37{ }^{\circ} \mathrm{C}$ in a $5 \% \mathrm{CO}_{2}$ atmosphere. HCT15 cells were cultured and seeded into 96-well plates approximately as $5 \times 104$ cells in each well and incubated for $48 \mathrm{~h}$. HCT15 cells were treated with different concentrations of synthesized Ag NPs $(10,20,50,70,100 \mathrm{~g} / \mathrm{ml})$. After treatment, the plates were incubated for $24-48 \mathrm{~h}$ to perform cytotoxic analysis using MTT assay. MTT (3-(4,5dimethylthiazol-2-yl)-2,5-diphenyltetrazolium bromide, a yellow tetrazole) was prepared at a concentration of $5 \mathrm{mg} / \mathrm{ml}$, and $10 \mathrm{ml}$ of MTT was added to each well and incubated for $4 \mathrm{~h}$. Purple color formazone crystals that formed were then dissolved in $100 \mathrm{ml}$ of dimethyl sulphoxide (DMSO). These crystals were observed at $570 \mathrm{~nm}$ in a multi well ELISA plate reader. Optical density value was subjected to percentage of viability using the following formula:

$$
\begin{aligned}
& \% \text { of cell viability } \\
& =\frac{\text { OD value of experimental sample }(\mathrm{Ag} N \mathrm{NP}) \times 100}{\text { OD value of experimental control (untreated) }}
\end{aligned}
$$

Cytomorphology observation

The cells were seeded at $1 \times 105$ cells/well into a six-well chamber plate and incubated overnight. Later, the medium was replaced with maintenance medium DMEM without FBS containing $20 \mathrm{~g} / \mathrm{ml} \mathrm{Ag} \mathrm{NPs} \mathrm{incubated} \mathrm{for} 48 \mathrm{~h}$. The cytomorphology was examined under Nikon inverted microscope.

\section{Propidium iodide staining}

HCT15 cells were plated at $5 \times 104$ cells/well into a sixwell chamber plate. At $>90 \%$ confluence, the cells were treated with Ag NPs for $48 \mathrm{~h}$. The cells were washed with PBS fixed in methanol: acetic acid (3:1, v/v) for $10 \mathrm{~min}$ and stained with $50 \mathrm{~g} / \mathrm{ml}$ Propidium iodide for $20 \mathrm{~min}$. Nuclear morphology of apoptotic cells with condensed/ fragmented nuclei was examined under Confocal microscope. 


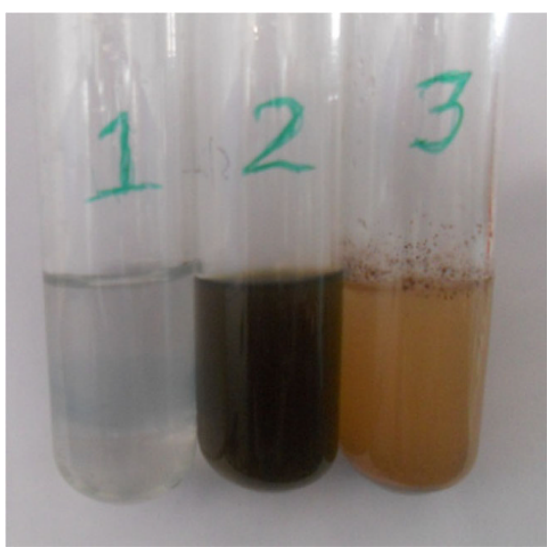

Fig. 1 Silver nitrate (1), plant extract (2), Ag NPs solution (3)

\section{Statistical analysis}

The grouped data were statistically evaluated using Microsoft excel worksheet. Values are presented as the mean $\pm \mathrm{SD}$ of the three replicates of each experiment.

\section{Results and discussion}

The present study was carried out to bio synthesize $\mathrm{Ag}$ NPs using leaf extract of $L$. reticulata and to study their biological properties. Nanoparticles are generally characterized by their size, shape, surface area, and dispersity. Homogeneity of these properties is important in many applications (Jiang et al. 2009). When the leaf extract was mixed with $\mathrm{AgNO}_{3}$ and incubated at room temperature, within $1 \mathrm{~h}$ of the reaction, its color changed from green to dark brown (Fig. 1), indicating the formation of Ag NPs. It is an efficient and rapid method, which was very well explained by other researchers who worked with different plant systems (Chandran et al. 2006; Li et al. 2007; Shankar et al. 2004). Change in color was due to the excitation of surface plasmon vibrations in the metal nanoparticles (Ahmad et al. 2003). Our results are in conformity with Bonde et al. (2012), who reported the formation of Ag NPs within $1 \mathrm{~h}$ of incubation. However, Dipankar and Murugan (2012) reported color change after 2-3 days indicating the slow reduction of the AgNO3 by the aqueous leaf extract of Iresine herbstii. An extract of Ocimum sanctum leaves was reported to reduce silver ions to nanoparticles within 8 min (Mallikarjun et al. 2011). The dissimilarity in the rates of bio-reduction observed may be due to the differences in the activities of the enzymes present in the plant leaf extracts.

It is generally recognized that $\mathrm{UV}-\mathrm{Vis}$ spectroscopy could be used to examine size- and shape-controlled

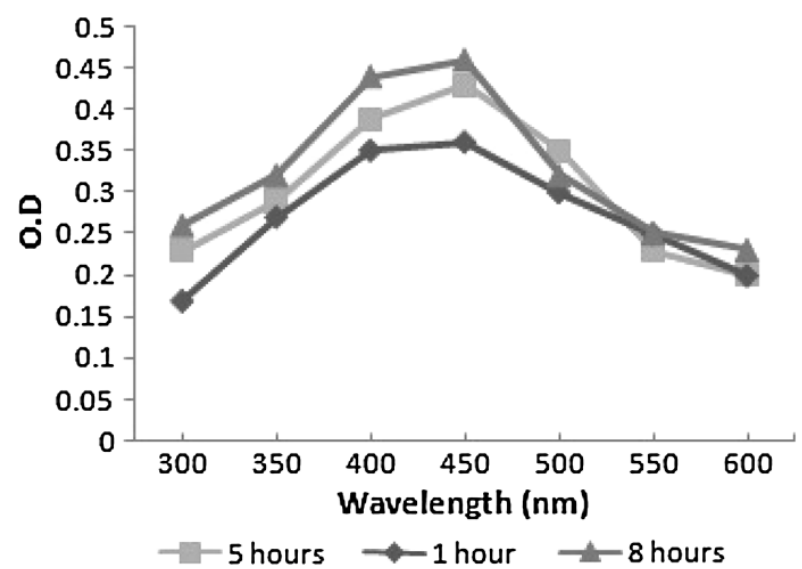

Fig. 2 UV-Vis spectral analysis of Ag NPs using leaf extracts of the L. reticulata

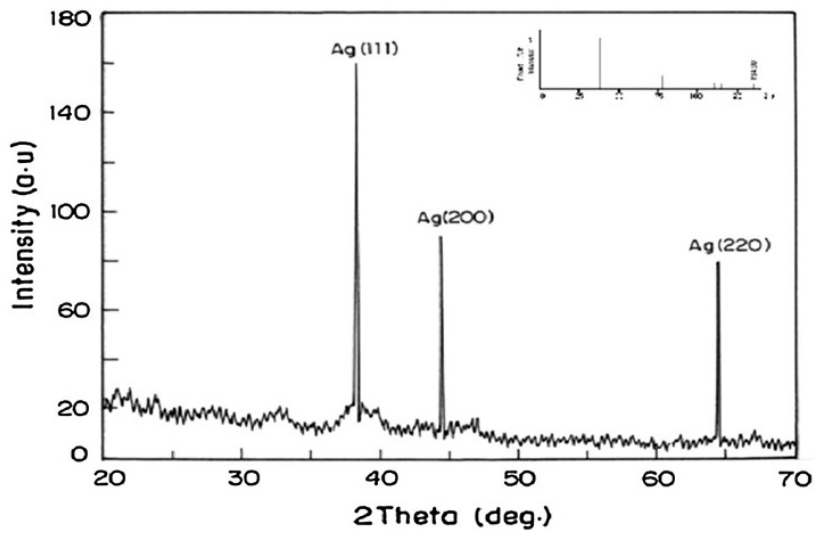

Fig. 3 The XRD pattern of Ag NPs

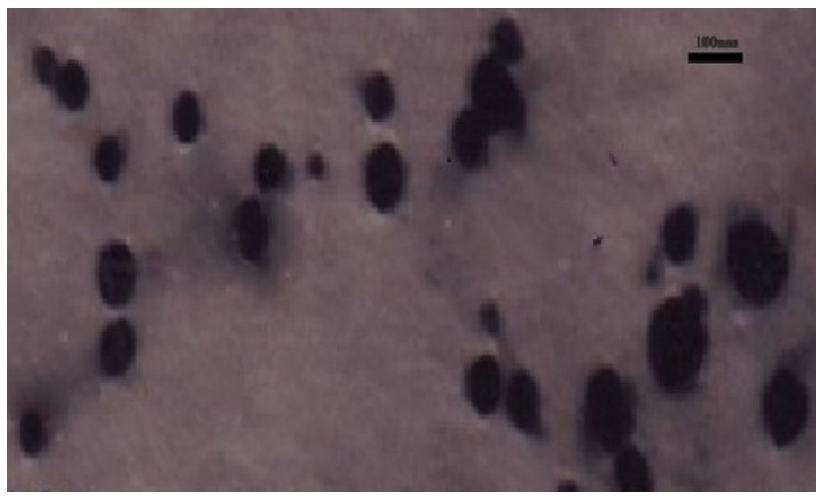

Fig. 4 The TEM image of Ag NPs

nanoparticles in aqueous suspensions. In order to verify the synthesis of Ag NPs, the test samples were subjected to UV-Vis spectrophotometric analysis (Fig. 2). This analysis showed the sharp absorbance at around $450 \mathrm{~nm}$ (Fig. 2), which was specific for Ag NPs. The UV-Vis absorption band in the current visible light region $(425-460 \mathrm{~nm})$ is an evidence of the presence of surface plasmon resonance 
Fig. 5 Antibacterial activity of different concentrations of biosynthesized Ag NPs against $S$. pneumonia (a) and $K$. pneumonia (b) $(1,2,3,4$ and 5 represents $25,50,75,100$ and $150 \mu \mathrm{g} / \mathrm{ml}$ of Ag NPs)
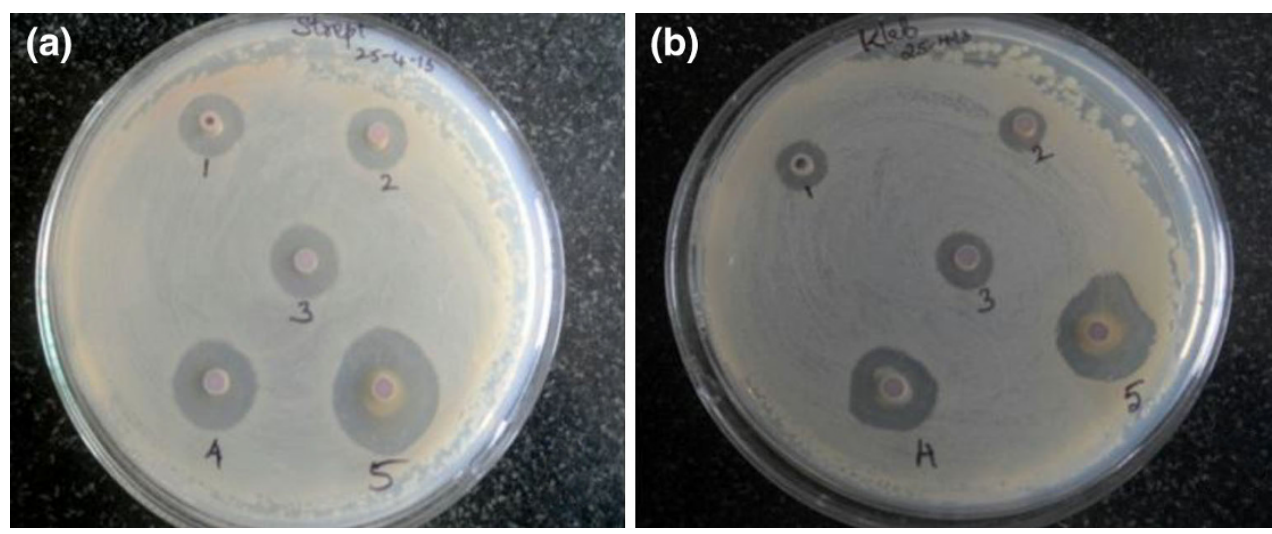

Table 1 In vitro antibacterial potential of biosynthesized Ag NPs using L. reticulata leaf extract

\begin{tabular}{|c|c|c|c|c|c|}
\hline \multirow[t]{2}{*}{ Ag NPs Conc. $(\mu \mathrm{g} / \mathrm{ml})$} & \multicolumn{5}{|c|}{ Zone of inhibition (mm) } \\
\hline & E. coli & K. pneumoniae & S. pneumoniae & M. luteus & B. subtilis \\
\hline 25 & $11.2 \pm 0.5$ & $9.6 \pm 0.6$ & $11.2 \pm 1.2$ & $8.7 \pm 1.4$ & $13.1 \pm 0.8$ \\
\hline 50 & $14.0 \pm 2.1$ & $10.3 \pm 2.1$ & $13.3 \pm 0.9$ & $11.0 \pm 1.6$ & $19.2 \pm 1.2$ \\
\hline 75 & $17.0 \pm 0.9$ & $12.4 \pm 1.8$ & $15.3 \pm 0.6$ & $14.0 \pm 0.4$ & $20.0 \pm 1.8$ \\
\hline 100 & $21.0 \pm 1.2$ & $17.6 \pm 1.1$ & $18.1 \pm 0.5$ & $17.1 \pm 0.5$ & $22.2 \pm 0.3$ \\
\hline 150 & $24.0 \pm 0.4$ & $20.7 \pm 1.0$ & $23.0 \pm 1.0$ & $17.0 \pm 1.5$ & $24.3 \pm 1.3$ \\
\hline
\end{tabular}

Values \pm SD indicates the replicates of three experiments

(SPR) of silver nanoparticles (Ankamwar et al. 2005; Kumar et al. 2010; Saxena et al. 2010; Mallikarjun et al. 2011; Bonde et al. 2012). The reduction was ascribed to the phenolics, terpenoids, polysaccharides, and flavones compounds present in the extract (Huang et al. 2007). The X-ray diffraction pattern of the biosynthesised Ag NPs from the leaf extract is shown in Fig. 3. XRD pattern of the biosynthesized $\mathrm{Ag}$ NPs showed characteristic peaks indexed to the crystalline planes (111), (200) and (220) of face-centered cubic silver. The values were in agreement with the findings of Joint Committee on powder diffraction (JCPD, standard file no. 04-0783). The sharpness of the peak clearly indicates that the particles are in the nanoregime. XRD pattern thus clearly illustrates that the silver nanoparticles formed in this present synthesis are crystalline in nature (Harekrishna et al. 2009). The applications of silver nanoparticles are dependent on their size and shape (Sivaraman et al. 2009). To get more evidence the s shape and size of Ag NPs were analyzed after $24 \mathrm{~h}$ of incubation using TEM (Fig. 4). In general, the nanoparticles were in spherical shape with varying sizes ranging from 50 to $70 \mathrm{~nm}$. One should note that TEM images were made by attaching a single drop of the nanoparticle solution onto a carbon film. Hence the single drop used for each sample cannot fully represent the entire solution. Also the use of the electron beam in acquiring the TEM image may

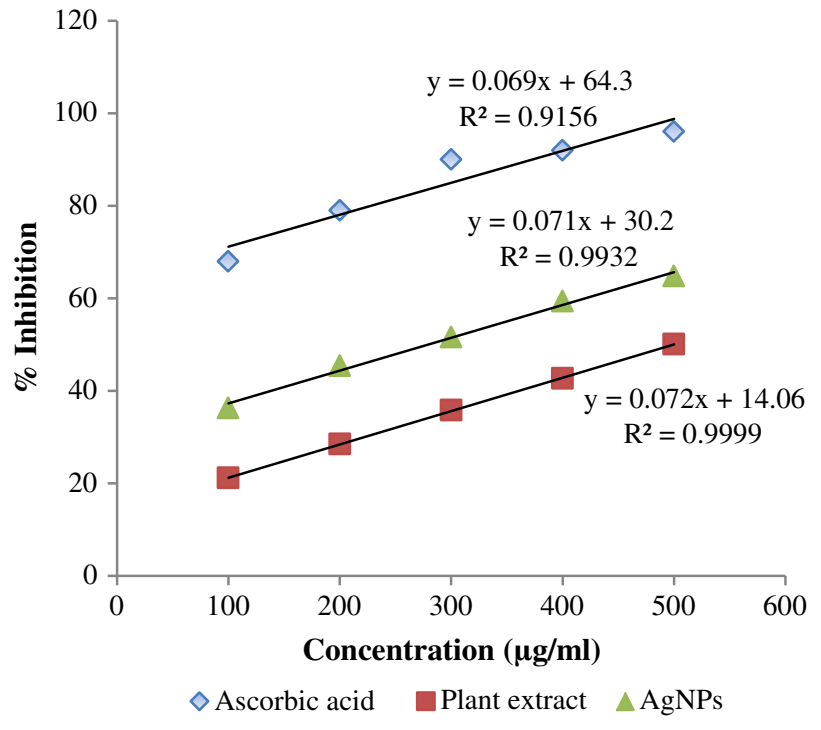

Fig. 6 DPPH assay of biosynthesized Ag NPs and ascorbic acid

somewhat alter the arrangement of the nanoparticles (Popov et al. 2006). In our study, TEM images were verified with multiple trials and evidenced that there is variation in particle sizes. However, we found very little variations in the sizes of the nanoparticles $(50-70 \mathrm{~nm})$. It is observed that most of the Ag NPs were of various spherical shapes, which fall closer to many of the silver nanoparticles 


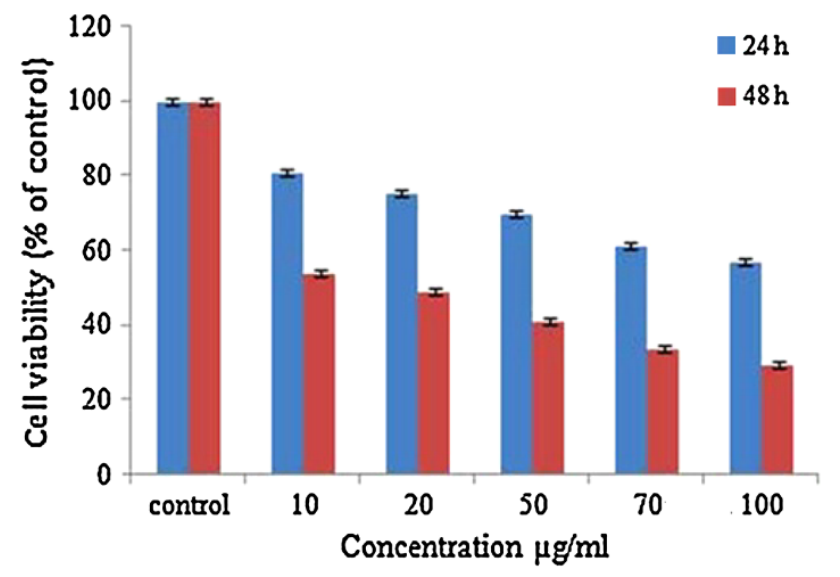

Fig. 7 The cytotoxicity assay of biosynthesized Ag NPs

produced by other plant materials (Shankar et al. 2004; Huang et al. 2007; Ali et al. 2011).

The present study clearly suggests the potential antibacterial activities of Ag NPs synthesized by methanol leaves extract of $L$. reticulata (Fig. 5). The results showed that antibacterial activity was dose dependant (Table 1). The maximum zone of inhibition with the B. subtilis
$(24.3 \pm 1.3 \mathrm{~mm})$, followed by E. coli $(20.0 \pm 0.4 \mathrm{~mm})$, was noticed at $150 \mu \mathrm{g} / \mathrm{ml}$ concentration of Ag NPs. The lowest zone of inhibition was observed with the M. luteus $(08.7 \pm 1.4 \mathrm{~mm})$ at $25 \mu \mathrm{g} / \mathrm{ml}$ concentration of $\mathrm{Ag}$ NPs. Irrespective of the microbes tested, zone of inhibition increased with increased concentration of Ag NPs. Similarly, Dipankar and Murugan (2012) have reported dosedependant inhibition by Ag NPs synthesized from Iresine herbstii leaf aqueous extracts. This might be due to denaturation of bacterial cell wall, blocking bacterial respiration, destabilization of outer membrane, and depletion of intracellular ATP (Maliszewska and Sadowski 2009). Ag NPs were more effective against Gram-positive bacterial strains than the Gram-negative bacteria strains. Further, the variation of the sensitivity between Gram-positive and Gram-negative bacterial isolates might be attributed by the membrane permeability (Ravikumar et al. 2010).

Antioxidants are compounds that protect cells against damaging effects of reactive oxygen species which can neutralize free radicals before they can do harm and undo some damage already caused to specific cells. Many medicinal plants are known to possess free radical scavenging molecules, such as phenolic compounds,

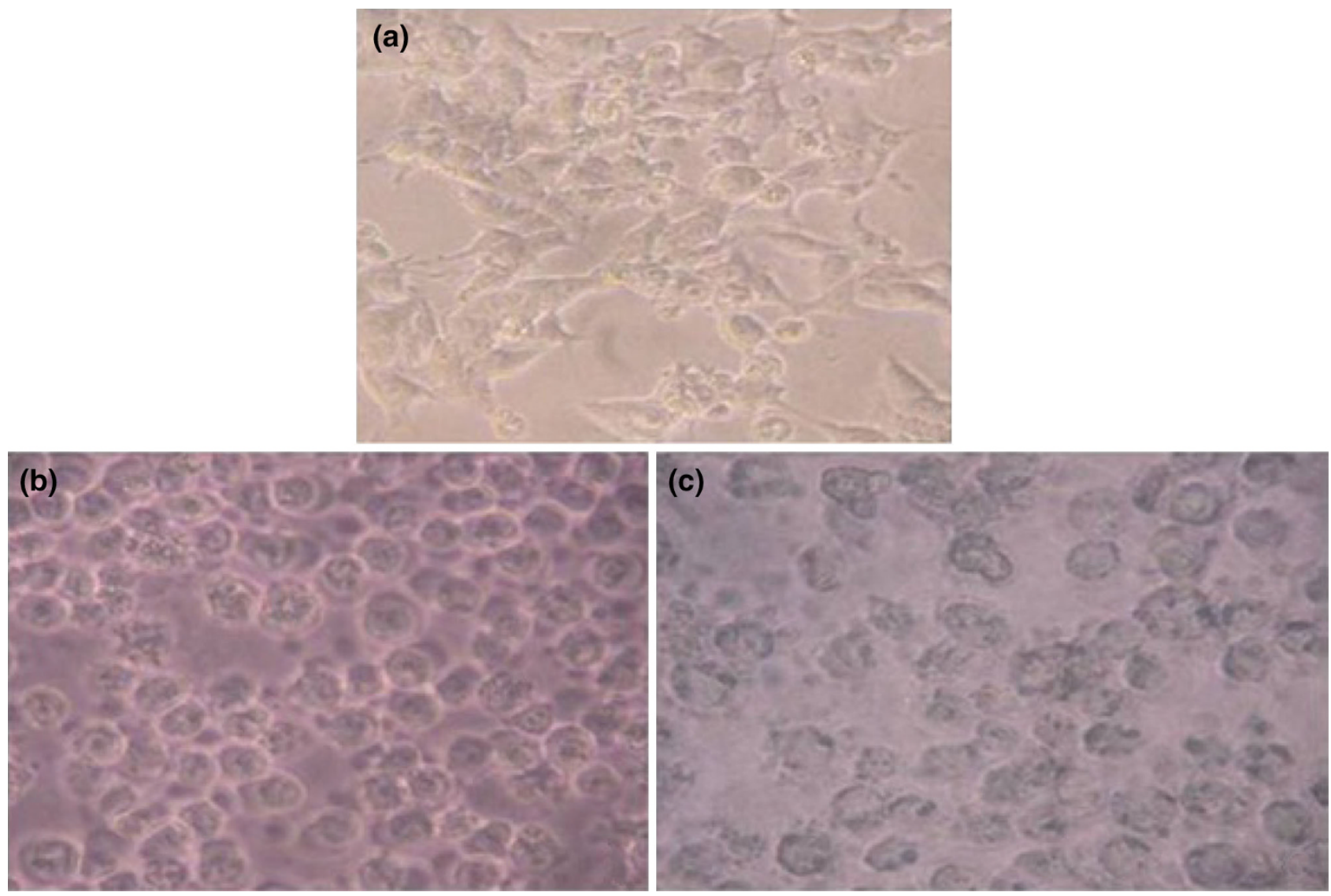

Fig. 8 Morphology of control and Ag NPs treated HCT15 colon cancer cells $\left(40 \times\right.$ magnification) a control; b $\mathrm{IC}_{50}$ concentration $(20 \mu \mathrm{g} / \mathrm{ml})$; c maximum concentration $(100 \mu \mathrm{g} / \mathrm{ml})$ 


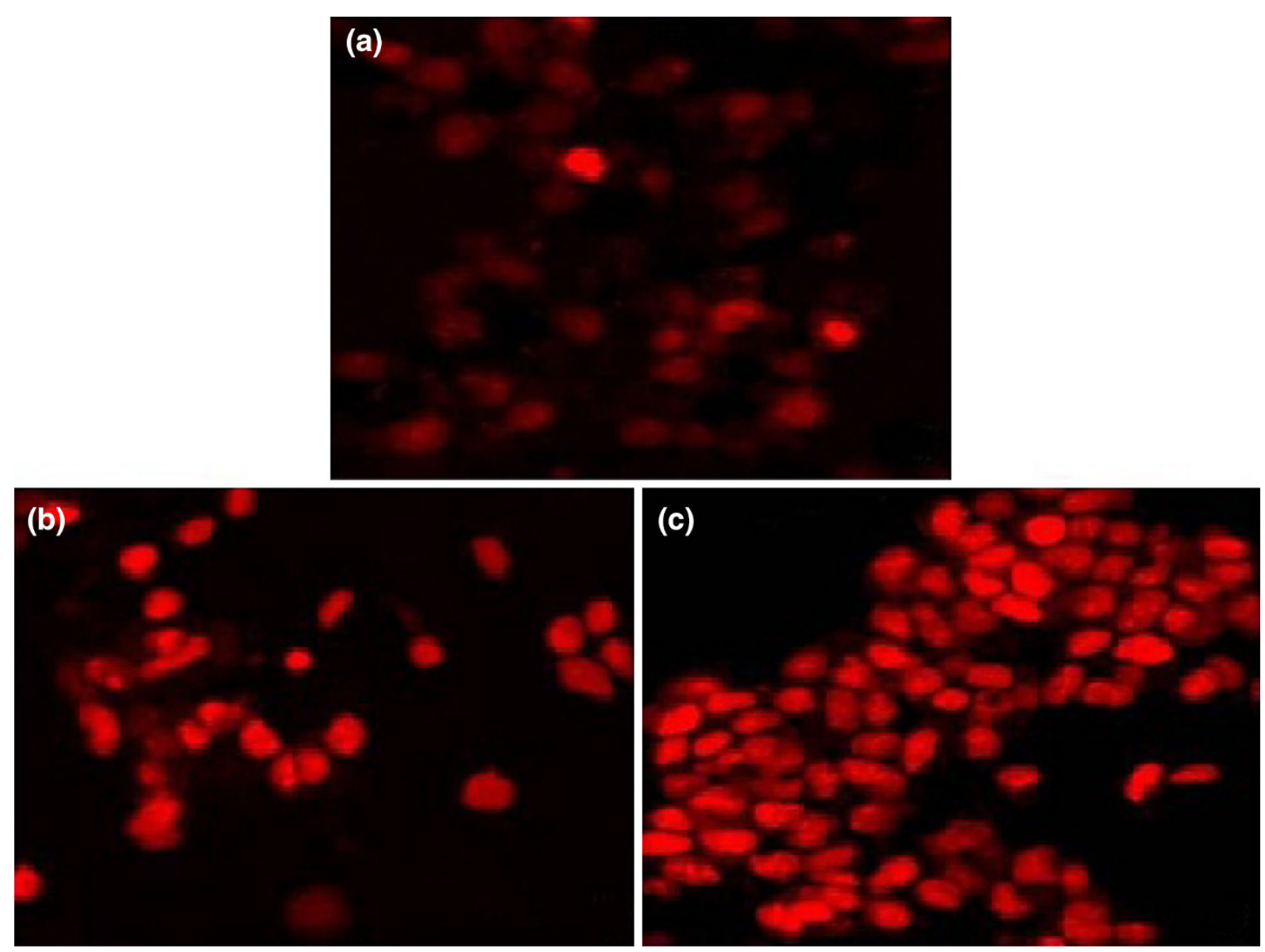

Fig. 9 Propidium iodide staining of HCT15 cells in both control and treated with Ag NPs $(20 \times$ magnification $)$ a control; b IC 50 concentration $(20 \mu \mathrm{g} / \mathrm{ml})$; c maximum concentration $(100 \mu \mathrm{g} / \mathrm{ml})$

terpenoids, vitamins, and some other endogenous metabolites, that are rich in antioxidant activity (Koleva et al. 2002). In the present study, antioxidant activity of the methanol extract of $L$. reticulata leaf and its Ag NPs were investigated by DPPH scavenging assay. DPPH stable free radical method is an easy, rapid and sensitive way to survey the antioxidant activity of a specific compound or plant extracts (Koleva et al. 2002). The results revealed the existence of effective radical scavenging activity of both plant extract and biosynthesized Ag NPs when compared with the standard, ascorbic acid (Fig. 6). The highest radical scavenging activity with $64.81 \%$ was observed in $\mathrm{Ag}$ NPs at $500 \mu \mathrm{g} / \mathrm{ml}$. The DPPH radical scavenging activities of plant extract and Ag NPs increased gradually in a dosedependent manner. Similar results are obtained by Dipankar and Murugan (2012) in I. herbstii aqueous leaf extracts. However, Ag NPs exhibited higher inhibition rate when compared to leaf extract, suggesting the potential benefits of Ag NPs as antioxidative agents.

The in vitro cytotoxic effects of silver nanoparticles were screened against HCT15 cancer cell line and viability of tumor cells was confirmed using MTT assay. The biosynthesized Ag NPs from were evaluated for their effect on cell viability against HCT15 cancer cell line at different concentrations. The biosynthesized Ag NPs showed a dosedependent decrease in cell viability. Increasing the time of incubation showed a further decrease in cell viability. The results suggested that the synthesized Ag NPs were very sensitive (Fig. 7). IC 50 value was found to be $20 \mu \mathrm{g} / \mathrm{ml}$ at $48 \mathrm{~h}$ of incubation. Microscopic observations were monitored using Nikon light inverted microscope wherein treated cells showed distinct cellular morphological changes indicating unhealthy cells, whereas the control appeared normal (Fig. 8). Control cells were irregular confluent aggregates with rounded and polygonal cells. Biosynthesized Ag NPs treated cells appeared to shrink and became spherical in shape, and cell spreading patterns were restricted when compared to control. To confirm whether the cytotoxic effect induced by Ag NPs biosynthesized from leaves extract of $L$. reticulata involves apoptotic changes, the nuclear condensation was studied by the propidium iodide staining method. In the case of control cells, a very negligible number of propidium iodide-positive cells were present. The cells treated with $20 \mu \mathrm{g} / \mathrm{ml}$ of biosynthesized 
Ag NPs showed more number of propidium iodide-positive cells (Fig. 9). The cytotoxic effects of silver are the result of active physicochemical interaction of silver atoms with the functional groups of intracellular proteins, as well as with the nitrogen bases and phosphate groups in DNA (Moaddab et al. 2011). There are only few studies on the cytotoxic effect of plant-based Ag NPs against Hep 2 cell line, HeLa cell line, HL 60 cell line (Rosarin et al. 2013; Sulaiman et al. 2013). However, our study is the first report on the use of HCT15 cancer cell line. Hence, this study will help in knowing about the potential benefits of $L$. reticulata Ag NPs for treating cancer. However, further studies on the mechanisms of action of Ag NPs on cytotoxicity are required to rate the risks and benefits of these plant-based nanoparticles.

\section{Conclusion}

In conclusion, the leaf extract of $L$. reticulata can be used efficiently to produce Ag NPs. This is a simple, eco-friendly process and has potent applications in biomedical and pharmaceutical applications. The bio-reduction observed may be due to the activities various plant metabolites present in the leaf extracts. XRD pattern thus clearly illustrates that the silver nanoparticles formed in this present synthesis are crystalline in nature. The nanoparticles were spherical in shape with varying sizes ranging from 50 to $70 \mathrm{~nm}$. The biosynthesized Ag NPs demonstrated an excellent antibacterial activity, antioxidant activity, and cytotoxic activity. Hence, Ag NPs can be explored as a new source of alternative medicine for treating many human ailments.

Open Access This article is distributed under the terms of the Creative Commons Attribution License which permits any use, distribution, and reproduction in any medium, provided the original author(s) and the source are credited.

\section{References}

Ahmad A, Mukherjee P, Senapati S, Mandal D, Khan MI, Kumar R (2003) Extracellular biosynthesis of silver nanoparticles using the fungus Fusarium oxysporum. Colloids Surf B 28:313-318

Ahmad N, Sharma S, Alam MK, Singh VN, Shamsi SF, Mehta BR (2010) Rapid synthesis of silver nanoparticles using dried medicinal plant of basil. Colloid Surf B 81:81-86

Ali DM, Thajuddin N, Jeganathan K, Gunasekaran M (2011) Plant extract mediated synthesis of silver and gold nanoparticles and its antibacterial activity against clinically isolated pathogens. Colloids Surf B Biointerfaces 85:360-365

Anjaria JV, Gupta I (1967) Studies on lactogenic property of Leptadenia reticulata and Leptaden tablet in goats, sheep, cows and buffaloes. Indian Vet J 44:967-974

Ankamwar B, Chaudhary M, Sastry M (2005) Biosynthesis of gold and silver nanoparticles using Emblica officinalis fruit extract, their phase transfer and transmetallation in an organic solution. J Nanosci Nanotechnol 5:1665-1671
Balaji DS, Basavaraja S, Deshpande R, Mahesh DB, Prabhakar BK, Venkataraman A (2009) Extracellular biosynthesis of functionalized silver nanoparticles by strains of Cladosporium cladosporioides fungus. Colloids Surf B 68(1):88-92

Bonde SR, Rathod DP, Ingle AP, Ade RB, Gade AK, Rai MK (2012) Murraya koenigii-mediated synthesis of silver nanoparticles and its activity against three human pathogenic bacteria. Nanosci Methods 1:25-36

Brunner TI, Wick P, Manser P, Spohn P, Grass RN, Limbach LK, Bruinink A, Stark WJ (2006) In vitro cytotoxicity of oxide nanoparticles: comparison to asbestos, silica, and effect of particle solubility. Env Sci Technol 40:4374-4381

Chandran SP, Chaudhary M, Pasricha R, Ahmad A, Sastry M (2006) Synthesis of gold nanotriangles and silver nanotriangles using Aloe vera plant extract. Biotechnol Prog 22:577-579

Chang W, Choi SCK, Soon SH, Bong KC, Hye JA, Min YL, Sang HP, Soo KK (2002) Antioxidant activity and free radical scavenging capacity between Korean medicinal plants and flavonoids by assay guided comparison. Plant Sci 163:1161-1168

Dipankar C, Murugan S (2012) The green synthesis, characterization and evaluation of the biological activities of silver nanoparticles synthesized from Iresine herbstii leaf aqueous extracts. Colloids Surf B 98:112-119

Harekrishna B, Dipak KB, Gobinda PS, Priyanka S, Sankar PD, Ajay M (2009) Green synthesis of silver nanoparticles using latex of Jatropha curcas. Colloids Surf A Physicochem Eng Asp 339:134-139

Huang J, Chen C, He N, Hong J, Lu L, Qingbiao L, Shao W, Sun D, Wang XH, Wang Y, Yiang X (2007) Biosynthesis of silver and gold nanoparticles by novel sun dried Cinnamomum camphora leaf. Nanotechnology 18:105-106

Jiang J, Oberdörster G, Biswas P (2009) Characterization of size, surface charge, and agglomeration state of nanoparticle dispersions for toxicological studies. J Nanopart Res 11:77-89

Koleva II, Van Beek TA, Linssen JPH, de Groot A, Evstatieva LN (2002) Screening of plant extracts for antioxidant activity: a comparative study on three testing methods. Phytochem Anal 13:8-17

Kumar V, Yadav SC, Yadav SK (2010) Syzygium cumini leaf and seed extract mediated biosynthesis of silver nanoparticles and their characterization. $\mathrm{J}$ Chem Technol Biotechnol 85:1301-1309

Li S, Shen Y, Xie A, Yu X, Qiu L, Zhang L, Zhang Q (2007) Green synthesis of silver nanoparticles using Capsicum annиит $\mathrm{L}$. extract. Green Chem 9:825-858

Maliszewska I, Sadowski Z (2009) Synthesis and antibacterial activity of of silver nanoparticles. J Phys Conf Ser 146(1) (Article ID 012024)

Mallikarjun K, Narsimha G, Dillip G, Praveen B, Shreedhar B, Lakshmi S (2011) Green synthesis of silver nanoparticles using Ocimum leaf extract and their characterization. Dig J Nanomater Biostruct 6:181-186

Moaddab S, Ahari H, Shahbazzadeh D, Motallebi AA, Anvar AA, Rahman-Nya J, Shokrgozar MR (2011) Toxicity study of nanosilver (Nanocid) on osteoblast cancer cell line. Int Nano Lett 1:11-16

Nabikha K, Kathiersan A, Raj M, Alikunhi N (2009) Synthesis of antimicrobial silver nanoparticles by callus and leaf extract from salt marsh plants, Sesuvium portulacastrum L. Colloids Surf Biointerfaces 79:488-493

Parashar UK, Saxenaa P, Srivastava A (2009) Bioinspired synthesis of silver nanoparticles. Dig J Nanomater Biostruct 4:159-166

Popov AK, Brummer J, Tanke RS, Taft G, Loth M, Langlois R, Wruck A, Schmitz R (2006) Synthesis of isolated silver nanoparticles and their aggregates manipulated by light. Laser Phys Lett 3(11):546-552 
Prabhu S, Poulose EK (2012) Silver nanoparticles: mechanism of antimicrobial action, synthesis, medical applications, and toxicity effects. Int Nano Lett 2:32

Rai M, Yadav A, Gade A (2009) Silver nanoparticles as a new generation of antimicrobials. Biotechnol Adv 27:76-83

Ravikumar S, Gnanadesigan M, Suganthi P, Ramalakshmi A (2010) Antibacterial potential of chosen mangrove plants against isolated urinary tract infectious bacterial pathogens. Int J Med Med Sci 2(3):94-99

Rosarin FS, Arulmozhi V, Nagarajan S, Mirunalini S (2013) Antiproliferative effect of silver nanoparticles synthesized using amla on Hep2 cell line. Asian Pac J Trop Med 6(1):1-10

Saxena A, Tripathi RM, Singh RP (2010) Biological synthesis of silver nanoparticles by using onion (Allium cepa) extract and their antibacterial activity. Dig J Nanomater Bios 5:427-432

Shankar SS, Ahmad A, Rai A, Sastry M (2004) Rapid synthesis of $\mathrm{Au}, \mathrm{Ag}$ and bimetallic Au core-Ag shell nanoparticles by using neem (Azadirachta indica) leaf broth. J Colloid Interface Sci 275:496-502

Sivarajan VV, Balachandran I (1994) Ayurvedic drugs and their plant sources. Oxford IBH Co. Pvt Ltd, India

Sivaraman SK, Elango I, Kumar S, Santhanam V (2009) A green protocol for room temperature synthesis of silver nanoparticles in seconds. Curr Sci 97(7):1055

Sudipta KM, KumaraSwamy M, Balasubramanya S, Anuradha M (2011) Cost effective approach for in vitro propagation of (Leptadenia reticulata Wight \& Arn.) - a threatened plant of medicinal importance. J Phytol 3(2):72-79

Sulaiman GM, Mohammed WH, Marzoog TR, Al-Amiery AA, Kadhum AA, Mohamad AB, Bagnati R (2013) Green synthesis, antimicrobial and cytotoxic effects of silver nanoparticles using Eucalyptus chapmaniana leaves extract. Asian Pac J Trop Biomed 3(1):58-63 